
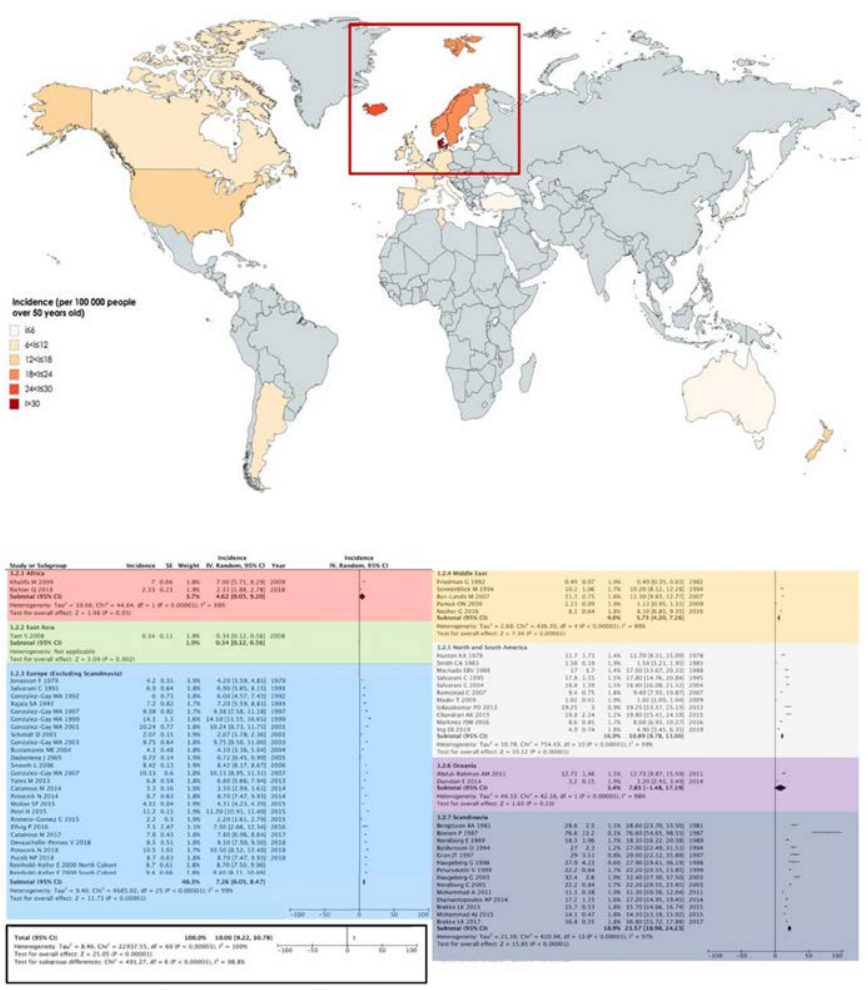

References:

[1] Floris A, Piga M, Cauli A, Salvarani C, Mathieu A. Polymyalgia rheumatica: an autoinflammatory disorder?. RMD Open. 2018;4(1):e000694. Published 2018 Jun 4. doi:10.1136/rmdopen-2018-000694

[2] Crow RW, Katz BJ, Warner JE, et al. Giant cell arteritis and mortality. J Gerontol A Biol Sci Med Sci. 2009;64(3):365-369. doi:10.1093/gero na/gln030

Acknowledgments: Both Daniel Semenov and Katherine Li equally contributed and sharing first authorship

Funding in part was from the Canadian Rheumatology Association summer studentship

Disclosure of Interests: Daniel Semenov: None declared, Katherine Li: None declared, Matthew Turk: None declared, Janet Pope Grant/research support from: AbbVie, Bristol-Myers Squibb, Eli Lilly \& Company, Merck, Roche, Seattle Genetics, UCB, Consultant of: AbbVie, Actelion, Amgen, Bayer, Boehringer Ingelheim, Bristol-Myers Squibb, Eicos Sciences, Eli Lilly \& Company, Emerald, Gilead Sciences, Inc., Janssen, Merck, Novartis, Pfizer, Roche, Sandoz, Sanofi, UCB, Speakers bureau: UCB

DOI: 10.1136/annrheumdis-2020-eular.3412

\section{FRI0546 GENDER DIFFERENCES OF RHEUMATIC DISEASES IN MEXICAN POPULATION: DATA FROM THE MEXICAN BIOLOGICS REGISTRY}

V. Rivera Teran ${ }^{1}$, D. Alpizar-Rodriguez ${ }^{1}$, S. Sicsik², F. Irazoque-Palazuelos ${ }^{2}$, D. Miranda ${ }^{2}$, D. Vega-Morales², J. C. Casasola ${ }^{2}$, S. Carriloº ${ }^{2}$, A. Castillo², S. Duran Barragan², O. Muñoz ${ }^{2}$, A. Paz ${ }^{2}$, A. Peña ${ }^{2}$, A. Torres ${ }^{2}$, D. X. Xibille Friedmann ${ }^{2}$, A. Ramos ${ }^{2}$, J. F. Moctezuma ${ }^{2}$, F. Aceves ${ }^{2}$, E. Torres ${ }^{2}$, N. Santana ${ }^{2}$, M. Vazquez ${ }^{2}$, E. Zamora ${ }^{2}$, F. Guerrero², C. Zepeda ${ }^{2}$, M. Rivera ${ }^{2}$, K. Alvarado ${ }^{2}$, C. F. Pacheco Tena ${ }^{2}{ }^{1}$ Colegio Mexicano de Reumatología, Unidad de Investigación, Mexico City, Mexico; ${ }^{2}$ Colegio Mexicano de Reumatología, Mexico City, Mexico

Background: Most autoimmune diseases are more prevalent in women. Symptom severity, disease progression, response to therapy and overall survival differ between males and females with rheumatic diseases.

Objectives: To identify the characteristics of autoimmune diseases presentation and treatment between male and female population using information from the Mexican Adverse Events Registry (BIOBADAMEX).

Methods: BIOBADAMEX is a Mexican ongoing cohort that collects the information of patients using biologic and biosimilar drugs since 2016. For this study we included all patients enrolled in the registry and compared baseline clinical and disease characteristics, treatment and presence of adverse events between genders. We used logistic regression to analyze univariable associations.
Table 1. Baseline characteristics in the cohort by sex

\begin{tabular}{|c|c|c|c|}
\hline & $\begin{array}{c}\text { Women } \\
n=532(82 \%)\end{array}$ & $\begin{array}{c}\text { Men } \\
n=123(18 \%)\end{array}$ & $\begin{array}{c}\text { Univariable }^{a} \\
\text { OR(95\% Cl) }\end{array}$ \\
\hline Age, median (IQR) & $53(44-60)$ & $47(34-55)$ & $1.02(1.0-1.1)^{\star}$ \\
\hline Body Mass Index, median (IQR) & $27(23-31)$ & $26(23-30)$ & $1.0(0.9-1.1)$ \\
\hline Smoking, n(\%) & $28(5)$ & $18(16)$ & $0.3(0.2-0.6)^{\star}$ \\
\hline Disease duration, median (IQR) & $9(4-16)$ & $7(2-13)$ & $1.0(1.0-1.1)^{\star}$ \\
\hline \multicolumn{4}{|l|}{ Diagnosis, $\mathrm{n}(\%)$ : } \\
\hline RA & $414(78)$ & $37(30)$ & $2.4(1.0-5.7)^{\star}$ \\
\hline AlJ & $12(2)$ & $5(4)$ & $0.5(0.1-1.9)$ \\
\hline AS & $37(7)$ & $56(46)$ & $0.1(0.1-0.4)^{*}$ \\
\hline PsA & $19(4)$ & $15(12)$ & $0.3(0.1-0.8)^{\star}$ \\
\hline SLE & $17(3)$ & $3(2)$ & $1.2(0.3-5.2)$ \\
\hline Others & $33(6)$ & $7(6)$ & 1 \\
\hline \multicolumn{4}{|c|}{ Disease Activity indexes, median (IQR) } \\
\hline DAS28 $^{\mathrm{a}}$ & $4.9(3.6-5.9)$ & $4.9(3.0-5.9)$ & $1.1(0.9-1.3)$ \\
\hline BASDAI $^{\mathrm{b}}$ & $4.8(2.9-8)$ & $5.3(2.8-7.5)$ & $0.9(0.8-1.1)$ \\
\hline ASDAS $^{\mathrm{C}}$ & $3.2(1.9-4.5)$ & $3.9(2.5-4.7)$ & $0.8(0.6-1.2)$ \\
\hline SLEDAI $^{d}$ & $14.5(5.0-19.5)$ & $25(25.0-31.0)$ & $0.6(0.4-1.1)$ \\
\hline High blood pressure, $\mathrm{n}(\%)$ & $77(15)$ & $14(12)$ & $1.3(0.7-2.4)$ \\
\hline Diabetes mellitus, n(\%) & $46(9)$ & $7(6)$ & $1.5(0.7-3.5)$ \\
\hline High cholesterol, n(\%) & $41(8)$ & $8(7)$ & $1.2(0.4-2.6)$ \\
\hline Other comorbidities, $\mathrm{n}(\%)$ : & $173(33)$ & $26(21)$ & $1.8(1.1-2.8)^{*}$ \\
\hline Use of previous biologic, $n(\%)$ : & $216(40)$ & $44(36)$ & $1.2(0.8-1.8)$ \\
\hline Use of steroids, $n(\%)$ : & 215 (42) & $34(29)$ & $1.7(1.1-2.7)^{\star}$ \\
\hline Use of DMARD, n(\%): & $418(79)$ & $89(72)$ & $1.4(0.9-2.2)$ \\
\hline Adverse events ${ }^{\mathrm{b}}, \mathrm{n}(\%)$ : & $69(13)$ & $14(11)$ & $1.2(0.7-2.1)$ \\
\hline Severe $^{\mathrm{b}}, \mathrm{n}(\%)$ : & $12(17)$ & $3(21)$ & $0.8(0.2-3.1)$ \\
\hline
\end{tabular}

Univariable logistic regression analysis. ${ }^{*} p<0.05 .{ }^{a} n=469,{ }^{b} n=99,{ }^{c} n=71,{ }^{d} n=19$,

Results: A total of 655 participants were analysed, of which $82 \%$ were female (Table 1). We found women were older with a median of 53 years compared to 46 years in men (OR 1.02, $\mathrm{Cl} 1.0-1.1)$. Smoking was higher in men (16\%) compared to women (5\%), (OR 0.3, $\mathrm{Cl} 0.2-0.6)$. Women had longer disease duration, 9 years compared to 7 years in men (OR 1, $\mathrm{Cl} 1.0-1.1)$. Rheumatoid arthritis (RA) was more prevalent in women (OR 2.7, $\mathrm{Cl}$ 1-6.9), while ankylosing spondylitis (AS) and psoriatic arthritis (PsA) were more prevalent in men (OR 0.2, $\mathrm{Cl} 0.1-0.4$, and OR 0.3, C 0.1-0.9 respectively). Women had more comorbidities than men (OR 1.8, $\mathrm{Cl} 1.1-2.8$ ) and used steroids more frequently (OR 1.7, $\mathrm{Cl} 1.1-2.7)$. Differences in disease activity were not found, however we noticed high activity scores among participants.

Conclusion: In our study we found sex differences regarding age and disease duration, being higher in women. As expected, the prevalence of RA was higher in women and $\mathrm{AS}$ and PSA in men. Overall, women used more steroids than men. An interesting finding was that patients had high disease activity. Future longitudinal analyses will allow us to analyse sex differences in disease progression and treatment response. References:

[1] Ortona E et al. Ann Ist Super Sanita 2016;52(2):205-12

[2] Ngo ST et al. Front Neuroendocrinol 2014;3(3):347-69

Disclosure of Interests: Vijaya Rivera Teran: None declared, Deshire Alpizar-Rodriguez: None declared, Sandra Sicsik: None declared, Fedra Irazoque-Palazuelos Consultant of: Bristol-Myers Squibb, Janssen, Pfizer Inc, Roche and UCB, Dafhne Miranda: None declared, David Vega-Morales: None declared, Julio Cesar Casasola: None declared, Sandra Carrilo: None declared, angel castillo: None declared, Sergio Duran Barragan: None declared, Omar Muñoz: None declared, Aleni Paz: None declared, Angélica Peña: None declared, Alfonso Tor res: None declared, Daniel Xavier Xibille Friedmann Consultant of: Lilly, Abbvie Speakers bureau: Lilly, Abbvie, Azucena Ramos: None declared, José Francisco Moctezuma: None declared, Francisco Aceves: None declared, Estefania Tor res: None declared, Natalia Santana: None declared, Miguel Vazquez: None declared, Erick Zamora: None declared, Francisco Guerrero: None declared Claudia Zepeda: None declared, Melanea Rivera: None declared, Kitzia Alvarado: None declared, Cesar Francisco Pacheco Tena: None declared DOI: 10.1136/annrheumdis-2020-eular.6091

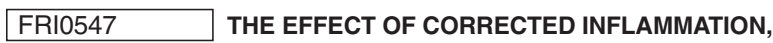 OXIDATIVE STRESS AND ENDOTHELIAL DYSFUNCTION ON FMD LEVELS IN PATIENTS WITH SELECTED CHRONIC DISEASES: A QUASI- EXPERIMENTAL STUDY}

M. Yilmaz ${ }^{1}$, M. Romano ${ }^{2}$, M. K. Basarali ${ }^{3}$, A. Elzagallaai ${ }^{4}$, M. Karaman ${ }^{1}$, Z. Demir ${ }^{1}$, M. F. Demir ${ }^{1}$, M. Seyrek ${ }^{5}$, F. Akcay ${ }^{1}$, N. Haksever ${ }^{6}$, D. Piskin ${ }^{4}$, R. Cimaz ${ }^{2}$, M. Rieder ${ }^{4}$, E. Demirkaya ${ }^{4} .{ }^{1}$ Epigenetic Health Solutions, Ankara, Turkey; ${ }^{2}$ Istituto Ortopedico Gaetano Pini, Milano, Italy; ${ }^{3}$ Ankara Provincial Health Directorate, Ankara, Turkey; ${ }^{4}$ Western University, London, Canada; ${ }^{5}$ Medisante Health Clinic, Ankara, Turkey; ${ }^{6}$ Yeditepe University, Istanbul, Turkey

Background: While the pathophysiology of chronic disorders varies there are three basic mechanisms - inflammation, oxidative stress and endothelial dysfunction - that are common in many chronic diseases. These mechanisms, 
which have a dynamic structure, are key to homeostasis. However, the failure of these mechanisms to work synchronously can lead to morbidity complicating the course of many chronic diseases.

Objectives: To evaluate the effect of anti-atherosclerotic liquid (AAL), anti-inflammatory capsules (AIC) and anti-oxidant liquid ( $A O L)$ supplementation on the flow-mediated dilatation (FMD), inflammatory, oxidative stress and endothelial dysfunction markers in patients with selected chronic diseases

Methods: We analyzed data of 178 patients from cohorts with selected chronic diseases (Rheumatoid arthritis, familial Mediterranean fever, DM type-2, Hypertension, Multiple sclerosis, Chronic obstructive pulmonary disease, Alzheimer disease and Cancer) in this quasi-experimental study. Endothelial dysfunction was determined by FMD and serum asymmetric dimethylarginine (ADMA) levels. Serum ADMA, high sensitive C-reactive protein (hs-CRP), serum PTX3, malondialdehyde (MDA), Cu/Zn-superoxide dismutase (Cu/Zn-SOD), glutathione peroxidase (GSH-Px) levels and FMD were studied in baseline and after 12 weeks of Morinda citrifolia (AAL, $3 \mathrm{ml}$ once per day), omega-3 (AIC, 3 capsules once per day) and extract with Alaskan blueberry and 21 different red purple fruit vegetables (AOL, $30 \mathrm{ml}$ once per day). Stepwise multivariate regression analysis evaluated the association of FMD with clinical and serologic parameters.

Results: Serum ADMA, MDA, PTX3, hsCRP and albumin levels, and proteinuria were significantly decreased and CuZn-SOD, GSH-Px and FMD levels were significantly increased following $A A L, A I C$ and $A O L$ therapies. FMD was negatively correlated with serum ADMA, MDA, PTX3, hsCRP levels, SBP and DBP and positively correlated to CUZn-SOD and eGFR levels both at baseline and after the 12-weeks treatment period. Multivariate regression analysis revealed that ADMA and PTX3 levels were independently related to FMD both before and after AAL, AIC and AOL therapies (Table 1, Figure 1).

Conclusion: Our study shows that serum ADMA, MDA, PTX3 levels are associated with endothelial dysfunction in patients with selected chronic diseases. Short-term AAL, AIC and AOL therapies significantly improves FMD and normalizes ADMA, PTX3, hsCRP and MDA. This may have implications for adjunctive therapy in a number of chronic disorders.

References:

[1] Yilmaz MI, Saglam M, Caglar K, Cakir E, Sonmez A, Ozgurtas T et al. The determinants of endothelial dysfunction in CKD: oxidative stress

Table 1. Analysis of association between change $(\Delta)$ in FMD and relevant parameters by univariate and multivariate linear regression analysis.

\begin{tabular}{lcc}
\hline & $\begin{array}{c}\text { Univariate } \\
\text { Rho }(\mathbf{p})\end{array}$ & $\begin{array}{c}\text { Multivariate } \\
\text { Beta }(\mathbf{p})\end{array}$ \\
\hline$\Delta$ FMD $(\%)\left(r^{2}=0.30\right)$ & & \\
Change & & $-0.25(0.01)$ \\
ADMA $(\mu \mathrm{mol} / \mathrm{l})$ & $-0.63(<0.001)$ & $-0.18(0.02)$ \\
MDA $(\mathrm{nmol} / \mathrm{ml})$ & $-0.58(<0.001)$ & $\mathrm{NS}$ \\
SOD $(\mathrm{U} / \mathrm{ml})$ & $0.48(<0.001)$ & $\mathrm{NS}$ \\
GSH $(\mathrm{U} / \mathrm{ml})$ & $0.02(0.75)$ & $\mathrm{NS}$ \\
HOMA & $-0.21(0.001)$ & $\mathrm{NS}$ \\
eGFR $\left(\mathrm{ml} / \mathrm{min} / 1.73 \mathrm{~m}^{2}\right)$ & $-0.03(0.62)$ & $-0.21(0.01)$ \\
hsCRP $(\mathrm{mg} / \mathrm{l})$ & $-0.45(<0.001)$ & $\mathrm{NS}$ \\
PTX3 $(\mathrm{ng} / \mathrm{ml})$ & $-0.49(<0.001)$ & $\mathrm{NS}$ \\
SBP $(\mathrm{mmHg})$ & $-0.26(<0.001)$ & $\mathrm{NS}$ \\
DBP $(\mathrm{mmHg})$ & $-0.11(0.12)$ & $\mathrm{NS}$ \\
Hemoglobin $(\mathrm{g} / \mathrm{dl})$ & $0.07(0.32)$ & $\mathrm{NS}$ \\
Total Cholesterol $(\mathrm{mg} / \mathrm{dl})$ & $-0.05(0.49)$ & $\mathrm{NS}$ \\
Triglyceride $(\mathrm{mg} / \mathrm{dl})$ & $-0.11(0.12)$ & $\mathrm{NS}$ \\
LDL $(\mathrm{mg} / \mathrm{dl})$ & $-0.12(0.07)$ & $\mathrm{NS}$ \\
HDL $(\mathrm{mg} / \mathrm{dl})$ & $0.02(0.82)$ & \\
HbA1c $(\%)$ & $-0.26(<0.001)$ & \\
\hline
\end{tabular}
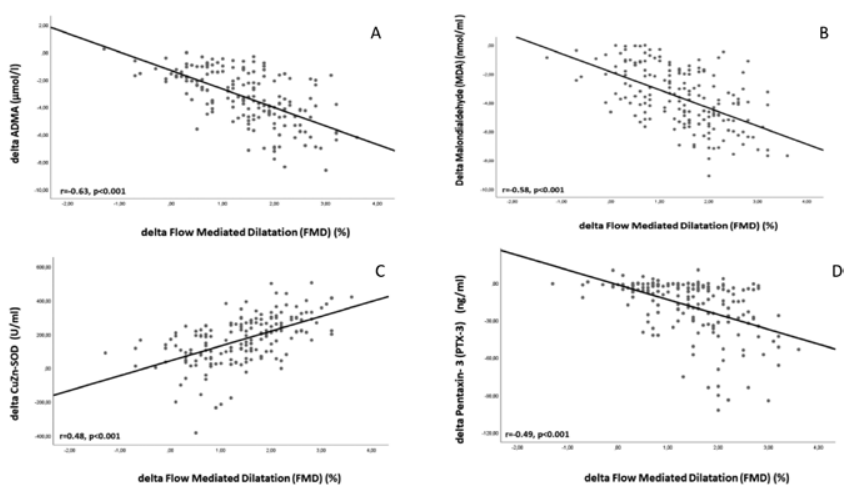

Figure 1. Scatter-plot graphs between FMD and ADMA, MDA, CuZn-SOD, PTX-3. and asymmetric dimethylarginine. Am J Kidney Dis. 2006;47(1):42-50 doi:10.1053/j.ajkd.2005.09.029

Disclosure of Interests: None declared

DOI: 10.1136/annrheumdis-2020-eular.4953

\section{FRI0548}

PREVALENCE AND THERAPY OF RHEUMATOLOGICAL ADVERSE EVENTS DUE TO IMMUNE CHECKPOINT INHIBITOR THERAPY

V. S. Schäfer ${ }^{1}$, S. H. Verspohl ${ }^{1}$, T. Holderried ${ }^{1}$, C. Behning ${ }^{2}$, P. Brossart ${ }^{1}$. ${ }^{1}$ University Hospital Bonn, Clinic for Internal Medicine III, Department of Oncology, Hematology and Rheumatology, Bonn, Germany; ${ }^{2}$ University Hospital Bonn, Institute for Medical Biometry, Informatics and Epidemiology, Bonn, Germany

Background: Immune checkpoint inhibitors (ICls) have improved cancer therapy and especially clinical outcomes for patients with many malignancies $\left[{ }^{1}\right]$. ICls lead to a higher immune system activity and subsequent attack of tumor cells. However, this effect can cause rheumatological immune related adverse events (rh-irAE), which have not yet been extensively studied.

Objectives: To determine the prevalence and type of rh-irAE in patients treated with ICls. Additionally, our study focused on duration, severity and therapy of rh-irAE as well as the correlation between tumor response rate and patients with or without rh-irAE.

Methods: We analysed 437 patients between January 2014 and October 2019, treated with ipilimumab (anti-CTLA-4) and/ or nivolumab (anti-PD-1) or pembrolizumab (anti-PD-1) at the Department of Oncology, Hematology and Rheumatology at the University Hospital in Bonn, Germany.

Results: Of the 437 patients, 260 (60\%) were males, 177 (40\%) were females with a mean age of 64 years $(S D \pm 14)$ at the beginning of the ICl-therapy. 152 patients $(34.8 \%)$ displayed at least one irAE.

We identified 20 patients (4.6\%) with a minimum of one rh-irAE due to ICl-therapy, seven of those had a pre-existing rheumatological disease. Those 20 patients were initially treated for melanoma, lung cancer, head and neck tumor and gastrointestinal carcinoma. Rh-irAE occurred in one patient $(2.6 \%)$ with ipilimumab, in nine patients $(4.8 \%)$ with nivolumab, in nine patients $(5.7 \%)$ with pembrolizumab and in one patient $(1.9 \%)$ with a combination of ipilimumab and nivolumab.

Arthralgia developed most frequently in nine of the 20 patients $(45 \%)$. Arthritis and myositis occurred with equal frequencies, in three cases each (3 patients, $15 \%)$. Furthermore, three of the 20 patients (15\%) developed a psoriatic arthritis and one patient $(5 \%)$ osteoarthritis. The time to the first rh-irAE after exposure to ICls was in median 100 days (IQR 45 - 406 days). Most rh-irAE were classified as moderate severe (CTCAE [Common Terminology Criteria of Adverse Events] grade $2: 55 \%)$.

15 patients $(75 \%)$ were treated with systemic corticosteroids. In three cases (15\%) additional therapy with methotrexate and in one patient $(5 \%)$ with tocilizumab was required. Other therapies including non-steroidal anti-inflammatory drugs and opioids were also used in eight patients. Even though patients benefited from $\mathrm{ICl}$ treatment, therapy had to be discontinued in nine of them (45\%).

Interestingly, patients with rh-irAE had a significantly higher tumor response rate compared to patients without any irAE ( $95 \%$ vs. $33 \%$; $p<0,0001)$.

Conclusion: Our results show, that rh-irAE occur under $\mathrm{ICl}$-therapy and in patients with higher tumor response. However, they are not the most frequent irAE after ICI exposure: $10.2 \%$ of all irAE were rheumatological (22 rh-irAE cases in 20 patients of a total of 216 irAE cases in 152 patients). As the use of ICls is increasing for different malignancies the incidence of rh-irAE can be expected to increase.

\section{References:}

[1] Ribas A, Wolchok JD. Cancer immunotherapy using checkpoint blockade. Science. 2018;359(6382):1350-1355. doi:10.1126/science.aar4060

[2] Spain L, Diem S, Larkin J. Management of toxicities of immune checkpoint inhibitors. Cancer Treat Rev. 2016;44:51-60. doi:10.1016/j.ctrv.2016.02.001

Acknowledgments

Disclosure of Interests: None declared

DOI: 10.1136/annrheumdis-2020-eular.3255

\section{FRI0549 \\ RISK OF INVASIVE FUNGAL INFECTION IN SYSTEMIC LUPUS ERYTHEMATOSUS: A NATIONWIDE POPULATION-BASED STUDY IN TAIWAN}

C. F. Su ${ }^{1}$, C. C. Lai ${ }^{1}$, T. H. LI ${ }^{2}$, Y. F. Chang ${ }^{3}$, Y. T. Lin ${ }^{4}$, C. Y. Tsai ${ }^{1}$, Y. S. Chang ${ }^{5}$. ${ }^{1}$ Taipei Veterans General Hospital, Department of Medicine, Division of Allergy, Immunology, Rheumatology, Taipei, Taiwan, Republic of China; ${ }^{2}$ Taichung Veterans General Hospital, Chiayi Branch, Department of Medicine, Division 